\title{
Multimedia Interaktif Konsep Gravitasi Berorientasi Pada Literasi Sains
}

\author{
Hapsari, Syarif Fitriyanto, Hermansyah*, Fahmi Yahya, Sri Nurul Walidain \\ Program Studi Pendidikan Fisika, Universitas Samawa \\ *Email: hermansyah.fis92@gmail.com
}

Received: 9 Oktober 2020; Accepted: 16 Desember 2020; Published: 17 Desember 2020

DOI: http://dx.doi.org/10.29303/jpft.v6i2.2097

\begin{abstract}
The objectives of this study were: 1) to determine the validity of interactive multimedia products oriented to science literacy in the concept of gravity and 2) to determine the response of prospective teachers to interactive multimedia products oriented to scientific literacy in the concept of gravity. This research is a type of research and development with the APPED model, but is limited to the evaluation stage. The research subjects were 2 validators and small-scale user trial subjects, namely 5 prospective physics teachers at Universitas Samawa in the second semester of the 2019/2020 academic year. The research and development results obtained were: 1) the product developed was categorized as very valid, with an average percentage of media validation reaching $87.3 \%$ and an average percentage of material validation reaching $82.4 \%$; 2) the response of pre-service teachers to the products developed obtained an average percentage of $83.6 \%$ and was included in the very good category.
\end{abstract}

Keywords: Interactive multimedia; gravity concept; science literacy

\section{PENDAHULUAN}

Pada abad 21, ilmu pengetahuan dan teknologi berkembang pesat. Perkembangan tersebut berdampak pada berbagai bidang kehidupan, salah satunya pendidikan. Pendidikan dituntut untuk menyiapkan sumber daya manusia yang bekualitas agar dapat survive dengan perkembangan zaman. Prasyarat kecakapan hidup abad 21 yang harus diterapkan dalam meningkatkan mutu pendidikan adalah literasi sains. Literasi sains mampu meningkatkan kualitas sumber daya manusia dan meningkatkan taraf hidup sehingga menjadi penentu kemajuan suatu bangsa. (Kemendikbud, 2017).

Literasi sains adalah kemampuan menggunakan pengetahuan ilmiah, untuk mengidentifikasi pertanyaan dan menggambarkan simpulan berdasarkan bukti untuk dapat memahami dan membantu pembuatan keputusan mengenai perubahan yang tercipta oleh aktivitas manusia (PISA, 2015). Literasi sains sangat penting dimiliki oleh setiap individu. Individu dengan kemampuan literasi sains akan menggunakan pertimbangan dan wacana tentang sains dan teknologi untuk menjelaskan fenomena secara ilmiah, mengevaluasi dan mendesain pertanyaan ilmiah, serta menginterpretasikan data dan bukti secara ilmiah (OECD, 2019).

Programme for International Student Assesment (PISA) merupakan survei yang bertujuan untuk mengetahui hasil sistem pendidikan yang berkaitan dengan kemampuan literasi peserta didik. Kategori yang diteliti dan dinilai meliputi membaca, matematika, dan sains. Sejak tahun 2000 hingga tahun 2018, hasil PISA Indonesia masih rendah terutama untuk kategori sains. Perolehan skor PISA Indonesia dari tahun 2000 sampai tahun 2018 dapat dilihat pada Gambar 1.

Rendahnya skor rata-rata Indonesia tersebut mencerminkan bahwa sebagian besar peserta didik di Indonesia belum mampu mengaplikasikan konsep untuk menyelesaikan suatu persoalan yang berkaitan dengan sains dan teknologi dalam kehidupan sehari-hari. 


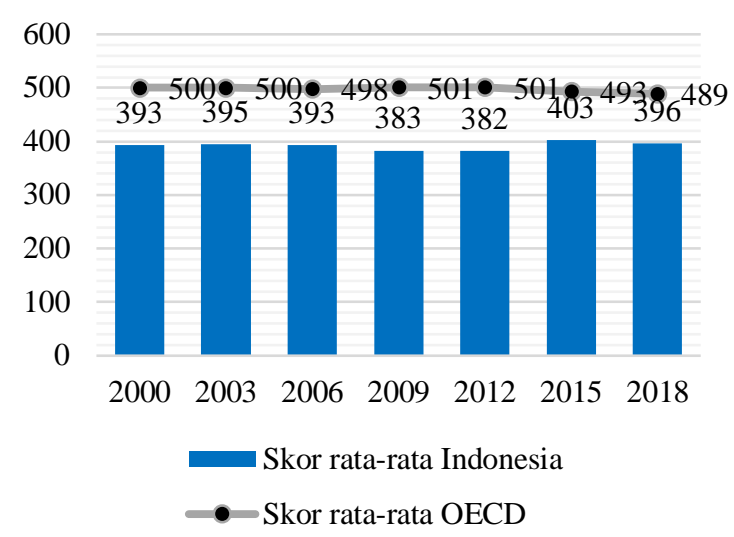

Gambar 1. Skor PISA Indonesia 2000 - 2018 pada Kategori Sains

Pembelajaran merupakan faktor terpenting dalam menentukan kualitas kemampuan literasi sains peserta didik. Menurut Harlen \& Qualter (2004) literasi sains dapat ditingkatkan dengan menerapkan pembelajaran sains yang mengedepankan pada pengembangan sikap, gagasan, dan keterampilan proses sains yang menekankan pada kegiatan saintifik inkuiri, dengan pembelajaran seperti itu maka akan meningkatkan antusiasme, minat, dan kekaguman peserta didik terhadap sains. Namun, faktanya pembelajaran yang merujuk pada peningkatan literasi sains belum optimal diterapkan dalam proses pembelajaran sains termasuk fisika sebagai salah satu cabang sains (Yulianti, 2017). Kemendikbud (2017) menyatakan konsep pendidikan sains sudah termuat dalam sistem pendidikan nasional dan pendekatan saintifik inkuiri, tetapi belum diterapkan secara tepat dan komprehensif dalam pelajaran sains sekalipun. Hal tersebut juga didukung oleh pendapat Pratiwi, Cari, \& Aminah (2019) yang menyatakan bahwa rendahnya literasi sains dikarenakan proses pembelajaran di instansi pendidikan tidak mendukung peserta didik dalam mengembangkan kemampuan literasi sains.

Faktor lain yang mempengaruhi rendahnya kemampuan literasi sains peserta didik yaitu kurangnya penggunaan sarana dan fasilitas belajar serta media pembelajaran digunakan pendidik dalam proses pembelajaran. Sarana dan fasilitas belajar berupa komputer dan laboratorium komputer belum dimanfaatkan secara maksimal dalam proses pembelajaran sains (Jayanthi, 2018). Padahal, penggunaan media berorientasi komputer menjadi bagian penting yang perlu dikembangkan dalam proses pembelajaran untuk memfasilitasi dan meningkatkan kemampuan literasi sains peserta didik (Latip \& Permanasari, 2015). Terutama di era abad 21 ini, perkembangan Informatics Technology (IT) sangat pesat, pendidik dituntut untuk mampu merancang pembelajaran dengan memanfaatkan berbagai jenis media belajar berorientasi IT yang sesuai, agar proses pembelajaran berlangsung efektif dan efisien (Sanjaya, 2013).

Berdasarkan pengalaman belajar peneliti di Universitas Samawa, permasalahan yang menjadi penyebab rendahnya literasi sains peserta didik, juga ditemui dalam pembelajaran fisika, khususnya pada mata kuliah fisika dasar. Dosen pengampuh mata kuliah fisika dasar masih dominan menggunakan sistem ceramah dalam proses pembelajaran. Media yang digunakan hanya berupa power point slide yang kurang menarik dan tidak interaktif. Untuk mendapatkan data yang valid dan update, peneliti melakukan penelitian awal yaitu mengidentifikasi metode dan media pembelajaran yang digunakan dalam pembelajaran fisika dasar. Dari Course Outline yang diberikan langsung oleh dosen pengampuh mata kuliah fisika dasar, peneliti menemukan fakta bahwa metode ceramah, diskusi dan tanya jawab masih dominan digunakan. Selain itu, peneliti juga mengambil data melalui angket analisis metode dan media pembelajaran yang digunakan dosen pengampuh mata kuliah fisika dasar, kepada peserta didik 
semester dua tahun ajaran 2019/2020 yang tengah menempuh mata kuliah tersebut. Hasil yang didapatkan dari pengisian angket tersebut yaitu: 1) Dikarenakan kondisi pandemik covid 19, pembelajaran dilakukan secara daring melalui aplikasi zoom. Namun, tetap dengan sistem ceramah dalam penyampaian materi pembelajaran; 2) Peserta didik hanya menggunakan komputer saat mengerjakan tugas daring yang diberikan dosen pengampuh; 3) Media pembelajaran yang dapat digunakan secara mandiri, hanya berupa power point biasa, yang tidak interaktif dan materi yang terdapat didalamnya hanya didominasi rumus-rumus, sehingga kurang memotivasi belajar peserta didik; dan 4) Dosen pengampuh mata kuliah fisika dasar belum pernah menggunakan atau memperkenalkan media pembelajaran interaktif berorientasi komputer. Berdasarkan hasil analisis masalah dan penelitian awal tersebut menunjukan bahwa dibutuhkan media pembelajaran berorientasi literasi sains yang merujuk pada peningkatan literasi sains peserta didik, memanfaatkan komputer dalam pengoperasiannya, dapat menarik minat peserta didik dalam belajar fisika dan dapat digunakan secara mandiri oleh peserta didik dimanapun dan kapanpun.

Multimedia interaktif merupakan salah satu media berorientasi komputer yang dapat dikembangkan untuk membantu pendidik dan peserta didik dalam proses pembelajaran. Multimedia interaktif merupakan suatu program pembelajaran yang berisi kombinasi teks, gambar, grafik, suara, video, animasi, simulasi secara terpadu dan sinergis dengan bantuan perangkat komputer atau sejenisnya untuk mencapai tujuan pembelajaran tertentu dimana pengguna dapat secara aktif berinteraksi dengan program (Surjono, 2017). Selain itu, multimedia interaktif dapat dioperasikan secara interaktif oleh peserta didik, sehingga mudah digunakan (Jayanthi,
2018). Penggunaan multimedia interaktif diharapkan dapat menyesuaikan berbagai cara belajar peserta didik yang berbeda-beda. Ada yang mudah menangkap informasi visual, sebagian lain lebih mudah bila ada suara, dan sebagian lain akan memahami dengan mudah atau lebih baik jika melakukannya dengan praktek (Gunawan, Harjono, \& Sutrio, 2015).

Hasil penelitian terdahulu, Latip \& Permanasari (2015) menunjukkan bahwa multimedia pembelajaran berorientasi literasi sains layak digunakan sebagai media dalam pembelajaran serta mampu memberikan peranan dalam peningkatan literasi sains peserta didik. Penelitian lain dilakukan oleh Jayanthi (2018), menunjukan bahwa penggunaan multimedia interaktif efektif dalam meningkatkan kemampuan literasi sains peserta didik. Selain itu, hasil penelitian penggunaan multimedia interaktif dalam pembelajaran fisika dapat memberikan pengaruh terhadap peningkatan kemampuan penguasaan konsep (Yulianci, Gunawan, \& Doyan, 2017) dan kemampuan berpikir kritis peserta didik (Husein, Herayanti, \& Gunawan, 2015), dan berpikir kreatif (Hermansyah, Gunawan, \& Herayanti, 2015). Sebagaimana diketahui bahwa literasi sains merupakan suatu kemampuan peserta didik mengkombinasikan berbagai kemampuan seperti pemahaman konsep dan berpikir untuk memecahkan masalah. Sehingga penelitian ini bertujuan bertujuan untuk mengembangkan multimedia interaktif berorientasi literasi sains pada materi gravitasi.

\section{METODE PENELITIAN}

Metode penelitian yang digunakan dalam penelitian ini adalah metode Research and Development $(R \& D)$. Menurut Borg and Gall (1996): "Educational Research and development $(R \& D)$ is a process used to 
develop and validate educational products" yang artinya penelitian dan pengembangan pendidikan merupakan proses yang digunakan untuk mengembangkan dan memvalidasi produk-produk pendidikan. Model penelitian dan pengembangan yang digunakan yaitu model pengembangan APPED yaitu Analisis dan Penelitian Awal, Perancangan, Produksi, Evaluasi, dan Diseminasi (Surjono, 2017), namun dibatasi sampai tahap evaluasi. Subyek penelitian dalam penelitian dan pengembangan ini adalah 2 validator dan subyek uji coba pengguna skala kecil yaitu 5 orang peserta didik semester dua tahun akademik 2019/2020 Universitas Samawa.

\section{HASIL DAN PEMBAHASAN}

Hasil

\section{Karakteristik Produk}

Multimedia interaktif berorientasi literasi sains dilengkapi dengan beberapa menu navigasi seperti menu login, halaman sambutan dan judul, menu home, menu petunjuk, menu pendahuluan, dan menu materi. Tampilan multimedia interaktif dapat dilihat pada Gambar 2.

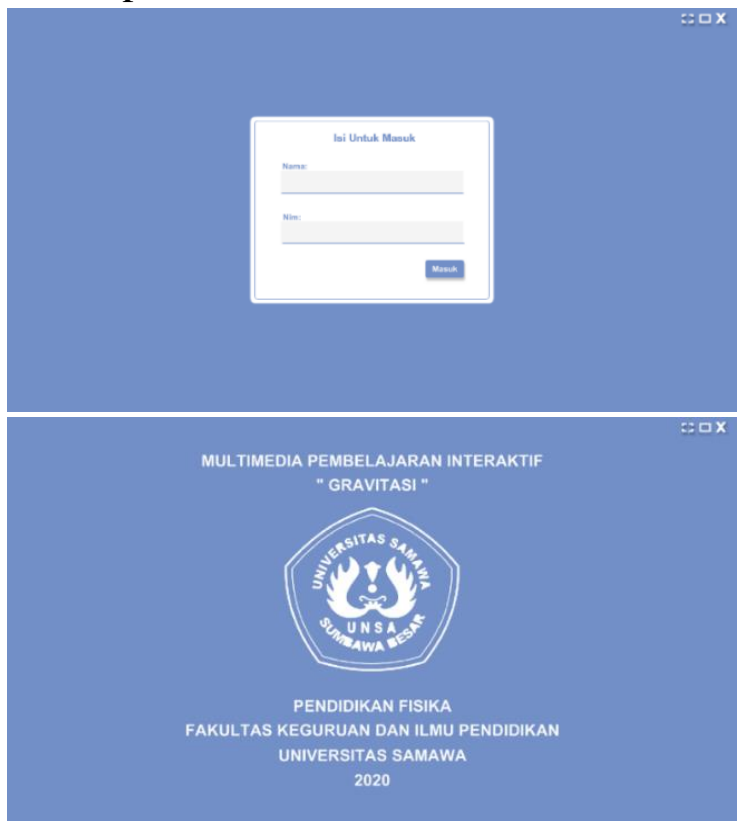

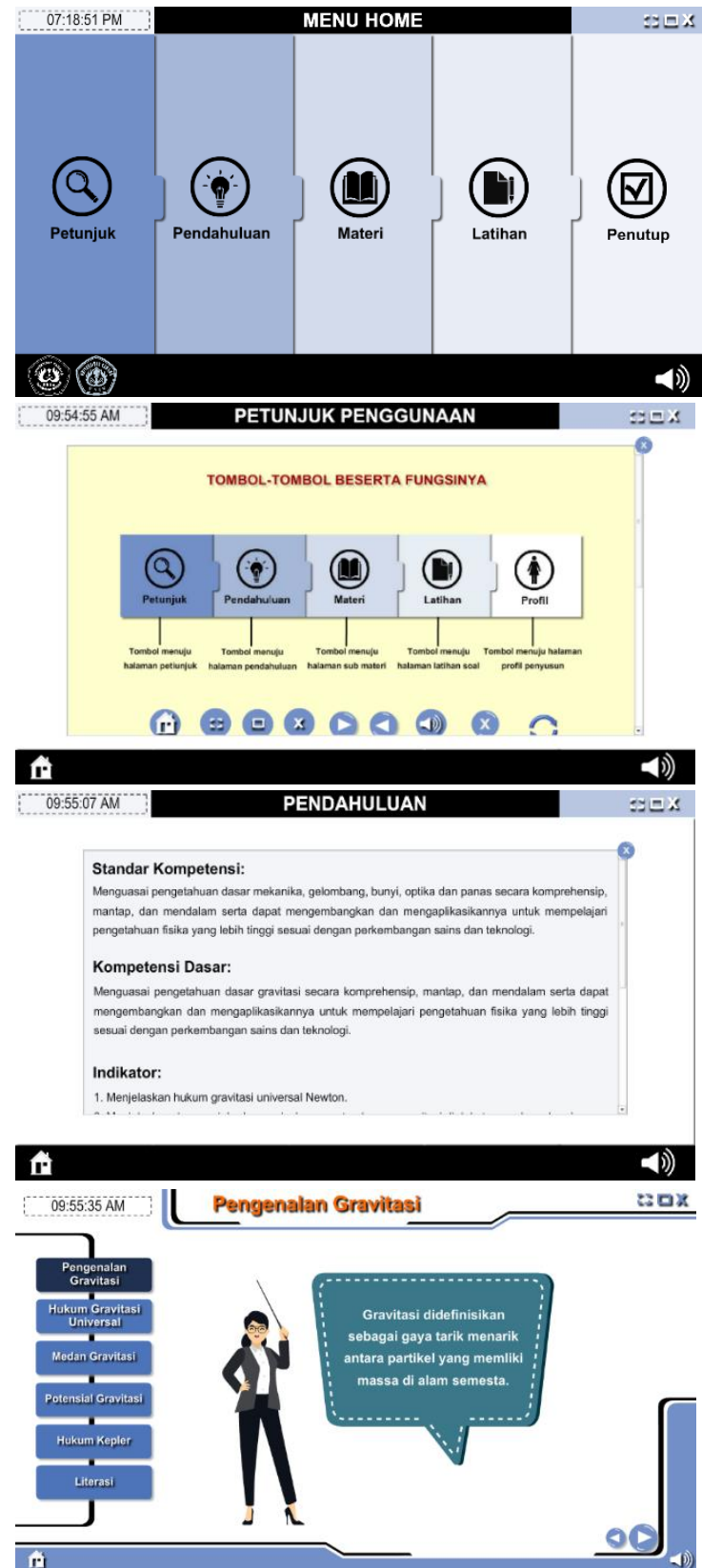

Gambar 2. Tampilan Umum Multimedia Interaktif

Isi dari menu materi disusun berdasarkan karakteristik bahan ajar menurut Chiappetta, Fillman, \& Sethna (1991).

a) Aspek Science As A Body of Knowledge (Sains sebagai Batang Tubuh Pengetahuan)

Aspek ini berisikan materi gravitasi yang meliputi pembahasan, fakta-fakta, konsep, hukum, dan teorinya. 


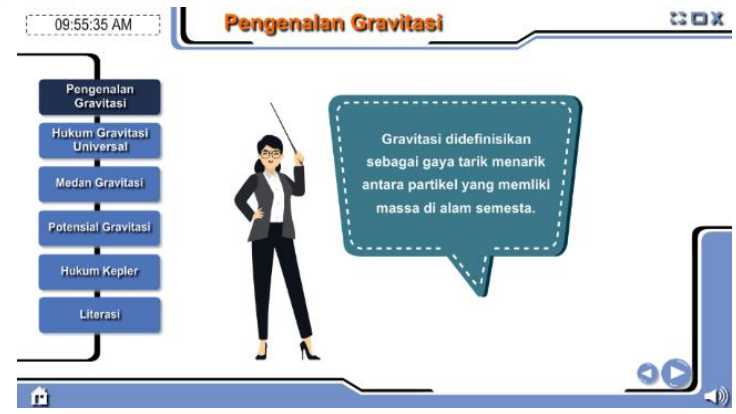

Gambar 3. Materi Pengenalan Gravitasi.

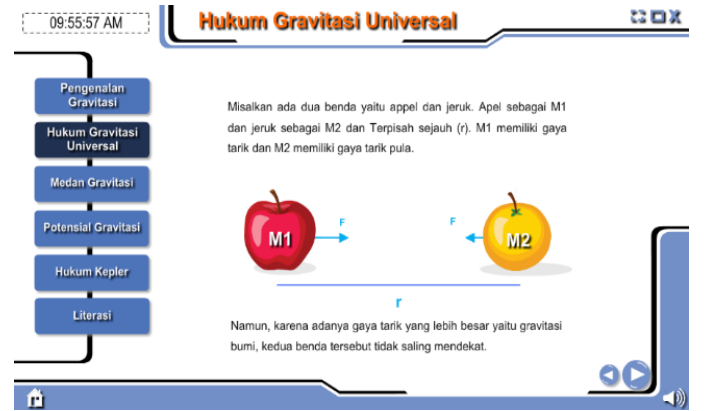

Gambar 4. Materi Hukum Gravitasi Universal.

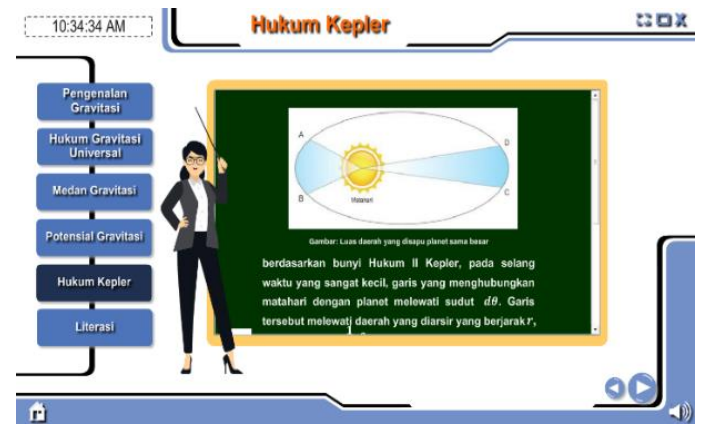

Gambar 5. Materi Hukum Kepler.

b) Science as The Way of Investigating (Sains sebagai Cara untuk Menyelidiki) Aspek ini diwakili oleh praktikum menghitung percepatan gravitasi dengan bandul matematis pada sub materi medan gravitasi. Melalui lembar praktikum, peserta didik diminta untuk melakukan percobaan sesuai panduan praktikum, kemudian mencatat data hasil pengamatan ke dalam format tabel yang telah disediakan, melakukan analisis data, dan membuat laporan praktikum.

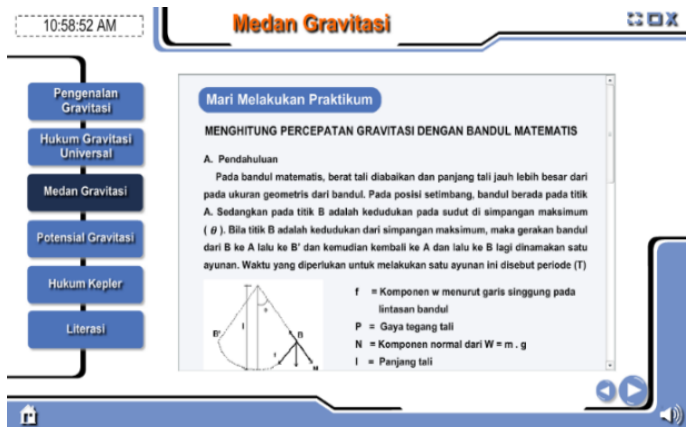

Gambar 6. Halaman Praktikum.

c) Science as A Way of Thinking (Sains sebagai Cara Berpikir)

Aspek ini ditunjukan pada halaman awal materi gravitasi, sub materi "pengenalan gravitasi" dan sub materi "literasi". Halaman awal materi gravitasi berisi stimulus berfikir berupa pertanyaanpertanyaan yang tujuannya untuk membuat peserta didik berfikir ilmiah tentang sebuah kasus yang biasa dilihat atau ditemui dalam kehidupan seharihari. Kemudian, pada sub menu pengenalan gravitasi disajikan wacana mengenai perkembangan teori gravitasi sebelum Isaac Newton menemukan teori gravitasi universalnya. Selain itu pada sub materi literasi terdapat bahan bacaan tentang bagaimana Sir Isaac Newton menemukan teori gravitasi.

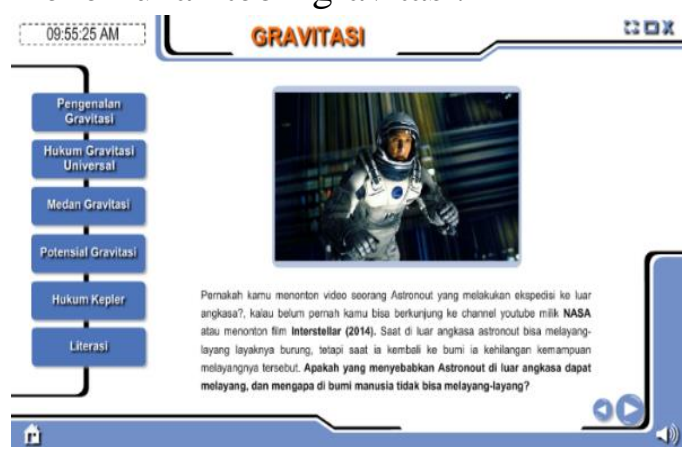

Gambar 7. Halaman Awal Materi Gravitasi Berisi Stimulus Berfikir Berupa Pertanyaan. 


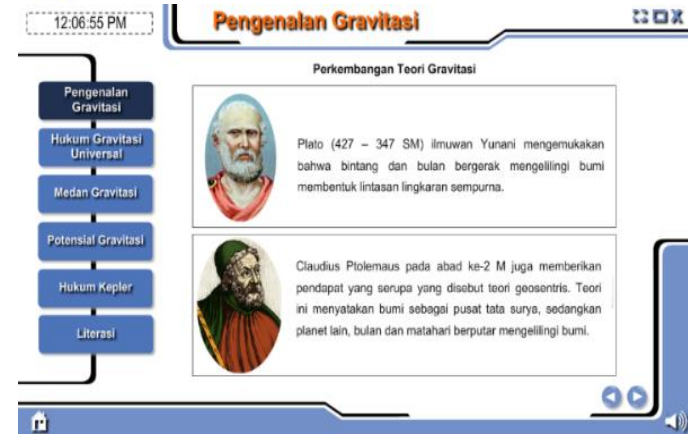

Gambar 8. Tampilan Halaman Sub Materi Perkembangan Gravitasi.

d) Interaction of Science, Technology, and Society (Interaksi Sains, Teknologi dan Masyarakat).

Aspek ini termuat dalam sub materi "literasi". Pada sub materi literasi terdapat 2 tombol yaitu tombol literasi baca dan literasi video. Tombol literasi baca fungsinya untuk menghantarkan pengguna menuju ke halaman yang berisi bahan bacaan. Halaman bahan baca memuat wacanah mengenai peristiwa yang ada hubungannya dengan materi gravitasi dan dampaknya dalam kehidupan contohnya gambaran tentang dampak bagi manusia apabila bumi tertarik oleh black hole. Selain itu, terdapat pula wacana terkait bidang karir yang berhubungan dengan gravitasi yaitu astronot. Sedangkan tombol literasi video berisi video pembelajaran dan informasi terkait gravitasi yang dapat ditonton oleh pengguna multimedia interaktif berorientasi literasi sains.

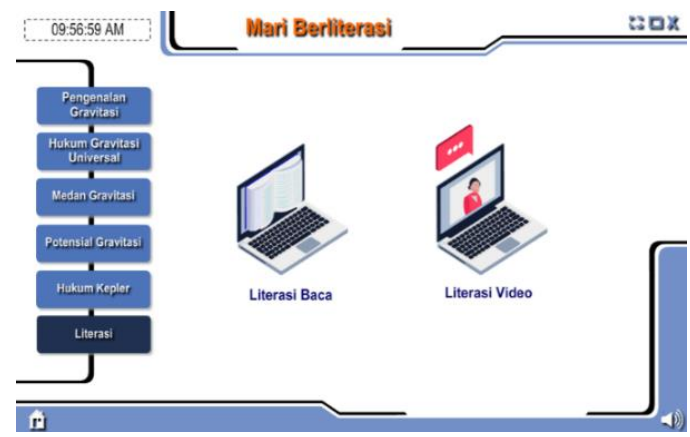

Gambar 9. Tampilan Tombol pada Menu Materi Literasi

\section{Validasi dan Respon Peserta Didik}

Hasil penelitian yang telah dilakukan peneliti berupa produk multimedia interaktif berorientasi literasi sains pada materi gravitasi, yang telah dinyatakan valid oleh validator dan direspon sangat baik oleh responden.

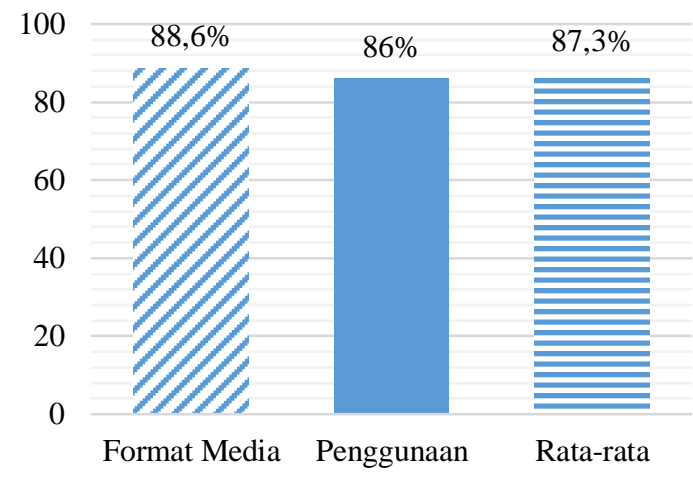

Gambar 10. Hasil Validasi Media.

Gambar 10 menunjukan persentase hasil validasi media terhadap produk multimedia interaktif berorientasi literasi sains. Persentase aspek format media mencapai $88.6 \%$ dari 7 -indikator penilaian, dan aspek penggunaan memperoleh persentase sebesar $86 \%$ dari 5-indikator penilaian. Rata-rata persentase dari kedua aspek tersebut adalah $87.3 \%$. Sehingga, hasil validasi media produk multimedia interaktif berorientasi literasi sains dinyatakan pada kategori sangat valid.

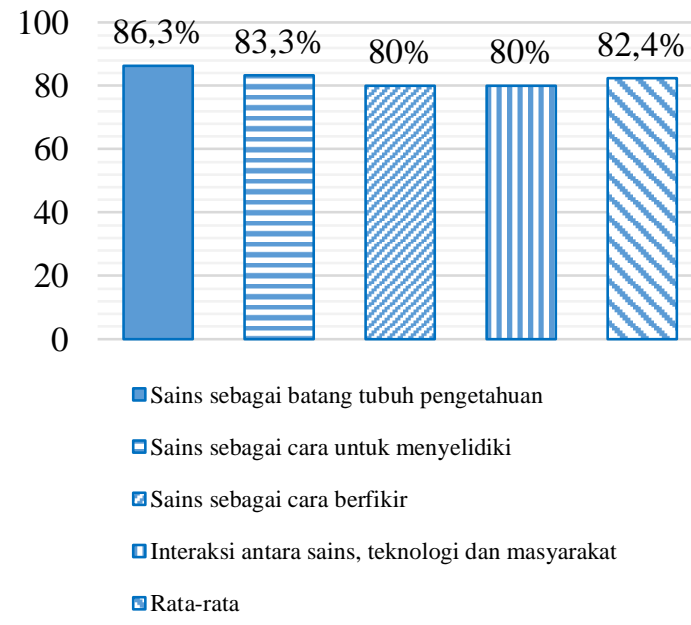

Gambar 11. Hasil Validasi Materi.

Gambar 11 menunjukan hasil validasi materi menunjukan kategori valid. Hal tersebut dibuktikan dari hasil rata- rata 
persentase aspek literasi sains, yang termuat dalam produk multimedia interaktif berorientasi literasi sains mencapai $82.4 \%$. Aspek literasi sains sebagai batang tubuh pengetahuan menyumbangkan persentase $86.3 \%$ dari 8 indikator penilaian, aspek sains sebagai cara untuk menyelidiki mencapai $83.3 \%$ dari 6 indikator penilaian, aspek sains sebagai cara berfikir dan interaksi antara sains, teknologi dan masyarakat sama-sama memperoleh persentase $80 \%$ dengan masingmasing indikator penilaian 9 dan 4 .

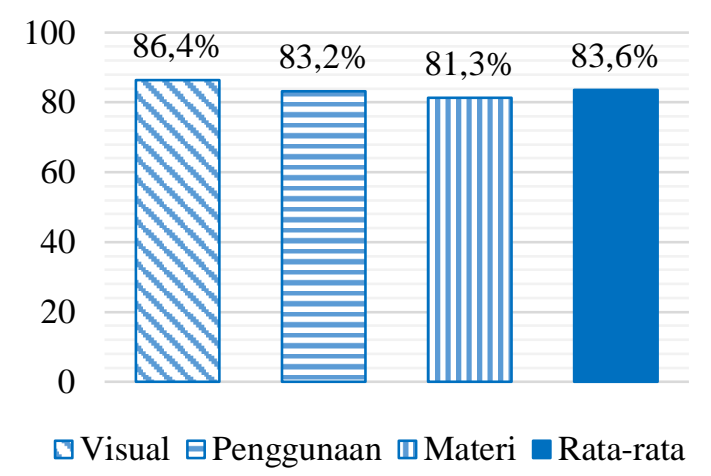

Gambar 12. Hasil Respon Peserta Didik.

Berdasarkan Gambar 12, diketahui bahwa hasil persentase rata-rata ketiga aspek penilaian mencapai $83.6 \%$. Artinya, produk multimedia interaktif berorientasi literasi sains termasuk dalam kategori sangat valid untuk digunakan dan diujicobakan ke pengguna skala besar. Aspek visual/tampilan memperoleh persentase $86.4 \%$ dari 5 indikator penilaian. Aspek penggunaan mendapat persentase $83.2 \%$ dari 10 indikator penilaian dan pada aspek materi, persentase yang diperoleh yaitu $81.3 \%$ dari 3 indikator penilaian.

\section{Pembahasan}

Arsyad (2002) menjelaskan bahwa salah satu prinsip yang perlu diperhatikan dalam pengembangan multimedia interaktif yaitu penggunaan font harus dengan ukuran normal dan layer tidak boleh terlalu padat. Produk multimedia interaktif berorientasi pada literasi sains telah didesain dengan mempertimbangkan prinsip tersebut. Hal ini dibuktikan oleh hasil persentase validasi media indikator pertama yaitu desain layout mendapat persentase kevalidan sebesar $95 \%$ yang menunjukan bahwa produk yang dikembangkan memiliki tampilan background dan kombinasi warna yang tepat. Indikator kedua yaitu teks dan tipografi mencapai persentase $93.3 \%$ sehingga menunjukan bahwa produk yang dikembangkan menampilkan font yang jelas dan mudah dibaca.

Indikator ketiga gambar memperoleh persentase kevalidan 93.3\%. Gambar yang ditampilkan dalam multimedia interaktif memiliki komposisi yang sesuai dengan konsep dan materi pelajaran yang dipilih dan memiliki kualitas tampilan yang baik. Kamila \& Ducha (2018) menyatakan bahwa tampilan gambar dalam multimedia interaktif harus konsisten. Gambar yang ditampilkan dalam multimedia interaktif harus memiliki resolusi atau jumlah pixel yang sama, sehingga kejelasan dan kualitas tampilan setiap gambar menjadi konsisten.

Menurut Arsyad (2002) pembelajaran dapat menjadi lebih menarik bila materi disajikan jelas dan runtut, dengan gambar yang berbeda-beda, penggunaan efek atau animasi yang dapat menimbulkan keingintahuan, merangsang peserta didik untuk berpikir dan menghibur. Indikator keempat animasi, hanya mencapai persentase $80 \%$ dan dinyatakan valid. Persentase tersebut menunjukan bahwa produk multimedia interaktif berorientasi literasi sains memuat animasi yang menarik dan sesuai dengan materi. Namun, animasi yang terdapat dalam produk yang dikembangkan hanya berupa transisi up and down dan left to right, sehingga animasi yang disajikan saat pergantian materi sudah dapat ditebak. Jadi, dari segi animasi belum mampu merangsang pengguna untuk berfikir.

Indikator ke lima yaitu audio dengan persentase $85 \%$. Perolehan $85 \%$ menunjukan 
kategori valid, pemilihan back sound dan ketepatan sound effect pada tombol sudah baik. Menurut validator back sound yang digunakan sudah tepat digunakan dalam pembelajaran fisika. Back sound yang dipilih tidak terlalu slow tempo dan tidak terlalu bising. Produk yang dikembangkan juga sudah memiliki tombol on/off music sehingga audio tidak menjadi masalah saat digunakan. Karim (2014) mengemukakan bahwa backsound dapat memberikan tekanan dan menciptakan suasana, sehingga musik atau backsound dapat mempengaruhi motivasi pengguna saat menggunakan multimedia interaktif karena kombinasi audio visual mendukung materi agar mudah diapahami peserta didik.

Indikator keenam yaitu video memperoleh persentase $83.3 \%$ dan dinyatakan valid. Pemilihan video yang disajikan dalam multimedia interaktif berorientasi literasi sains sesuai dengan konsep gravitasi, memiliki resolusi dan kualitas video yang baik. Menurut Asyhar (2012), kriteria video pembelajaran yang baik dan perlu diperhatikan adalah sebagai berikut: 1) Jelas dan rapi, 2) Jernih dan menarik, 3) Tepat sasaran, 4) Sesuai dengan topik pelajaran, 5) Sesuai dengan tujuan pembelajaran, 6) Praktis, 7) Kualitas baik, 8) Ukurannya sesuai dengan lingkungan belajar.

Indikator ketujuh yaitu ketersediaan navigasi dan interactive link memperoleh persentase $90 \%$. Dari hasil persentase tersebut dapat dilihat bahwa multimedia interaktif berorientasi literasi sains yang dikembangkan memiliki tombol navigasi dan kinerja interaktif link setiap tombol berfungsi dengan tepat.

Aspek yang kedua yaitu penggunaan memperoleh persentase $86 \%$ dan berada pada kategori sangat valid, hal tersebut menunjukan bahwa multimedia interaktif berorientasi literasi sains yang dikembangkan dapat digunakan dimanapun dan kapanpun (fleksibel), memuat petunjuk penggunaan, lancar saat digunakan dan tidak error saat diberikan perintah oleh pengguna serta selalu merespon setiap input yang diberikan pengguna. Hal tersebut sejalan dengan penelitian yang dilakukan oleh Kamila \& Ducha (2018), multimedia interaktif termasuk dalam kategori sangat valid bila multimedia dilengkapi dengan petunjuk penggunaan yang jelas, multimedia dilengkapi dengan tombol menu yang bisa dioperasikan dengan baik, dan saat dioperasikan multimedia tidak macet atau error.

Pada validasi materi, aspek yang pertama yaitu aspek sains sebagai batang tubuh pengetahuan terdiri dari 8 indikator. Aspek ini mendapat persentase kevalidan tertinggi sebesar $86.3 \%$ dan berada pada kategori sangat valid. Dari persentase yang didapat menunjukan bahwa produk multimedia interaktif berorientasi literasi sains menyajikan fakta, konsep, prinsip, hukum-hukum, hipotesis, teori dan model serta stimulus bagi peserta didik. Alasan tingginya persentase sains sebagai batang tubuh pengetahuan adalah karena produk multimedia interaktif yang dikembangkan masih menggunakan model tutorial sehingga materi pembelajaran gravitasi disajikan lebih banyak dibandingkan aspek yang lain. Menurut penelitian yang dilakukan Yuliyanti \& Rusilowati (2014) aspek pengetahuan sains dalam bahan ajar literasi sains selalu dominan dibandingkan dengan ketiga kategori lainnya.

Aspek kedua yaitu sains sebagai cara menyelidiki mendapat persentase $83.3 \%$ dari rata-rata persentase 6 indikator penilaian. Berdasarkan persentase rata-rata tersebut produk multimedia interaktif memiliki konten yang mengharuskan peserta didik menjawab pertanyaan melalui sebuah grafik dan tabel, membuat kalkulasi, menerangkan 
jawaban dan melibatkan peserta didik dalam eksperimen.

Aspek ketiga yaitu sains sebagai cara berfikir mencapai persentase $80 \%$ yang artinya valid. Jadi, produk yang dikembangkan memuat konten penggambaran seorang ilmuwan melakukan eksperimen, menunjukan perkembangan historis sebuah ide, menekankan sifat empiris dan objektivitas ilmu sains, mengilustrasikan sebuah asumsi, memberikan hubungan sebab akibat, mendiskusikan fakta dan bukti serta menyajikan metode ilmiah dan pemecahan masalah.

Aspek keempat adalah interaksi sains, teknologi dan masyarakat memperoleh persentase $80 \%$ yang menunjukan bahwa produk multimedia interaktif menyajikan gambaran kegunaan ilmu sains dan teknologi bagi kehidupan sehari-hari, menunjukan efek negatif dari sains dan teknologi bagi masyarakat, mendiskusikan masalahmasalah sosial yang berkaitan dengan ilmu sains dan menyebutkan contoh karir dan pekerjaan di bidang sains dan teknologi.

Pada hasil respon calon guru menunjukan bahwa multimedia interaktif berorientasi literasi sains termasuk dalam kategori sangat baik digunakan. Menurut responden, multimedia interaktif berorientasi literasi sains sangat mudah digunakan, tidak macet dan tidak error saat diberikan perintah, dan menciptakan suasana baru, serta memotivasi dalam belajar fisika. Hal ini sesuai dengan penelitian yang dilakukan oleh Yulianingsih, Habsya, \& Siswanto (2017) yang menyatakan bahwa multimedia interaktif dapat dijadikan sebagai alternatif belajar yang lebih menyenangkan sehingga mampu menumbuhkan semangat peserta didik dalam belajar. Selain itu, penelitian Kamila \& Ducha (2018) menghasilkan multimedia interaktif yang bisa dioperasikan dengan baik, dan saat dioperasikan multimedia tidak macet atau error maka dinyatakan dalam kategori sangat valid.

\section{PENUTUP}

Berdasarkan hasil penelitian yang telah dilakukan maka diperoleh simpulan bahwa multimedia interaktif berorientasi literasi sains pada konsep gravitasi sangat valid dan sangat praktis untuk digunakan dalam proses pembelajaran. Diharapkan bagi peneliti berikutnya untuk melihat efektivitas dari penggunaan multimedia interaktif ini sehingga media ini dapat dikatakan layak untuk digunakan dalam proses pembelajaran.

\section{REFERENSI}

Arsyad, A. (2002). Media pembelajaran, edisi 1. Jakarta: PT. Raja Grafindo Persada, 36.

Asyhar, R. (2012). Kreatif mengembangkan media pembelajaran.

Gall, M. D., Borg, W. R., \& Gall, J. P. (1996). Educational Research: An Introduction. Longman Publishing.

Chiappetta, E. L., Fillman, D. A., \& Sethna, G. H. (1991). A Method To Quantify Major Themes of Scientific Literacy In Science Textbooks. Journal of Research in Science Teaching, 28(8), 713-725.

Gunawan, G., Harjono, A., \& Sutrio, S. (2017). Multimedia Interaktif dalam Pembelajaran Konsep Listrik bagi Calon Guru. Jurnal Pendidikan Fisika dan Teknologi, 1(1), 9-14.

Harlen, W., \& Qualter, A. (2004). The Teaching of Science in Primary Schools. David Fulton Publishers.

Hermansyah, H., Gunawan, G., \& Herayanti, L. (2017). Pengaruh penggunaan laboratorium virtual terhadap penguasaan konsep dan kemampuan berpikir kreatif siswa pada materi getaran dan gelombang. Jurnal Pendidikan Fisika dan Teknologi, 1(2), 97-102. 
Husein, S., Herayanti, L., \& Gunawan, G. (2017). Pengaruh penggunaan multimedia interaktif terhadap penguasaan konsep dan keterampilan berpikir kritis siswa pada materi suhu dan kalor. Jurnal Pendidikan Fisika dan Teknologi, 1(3), 221-225.

Jayanthi, D. (2018). Pengembangan Multimedia Interaktif Berorientasi Inkuiri Terbimbing untuk Meningkatkan Kemampuan Literasi Sains dan Self-Efficacy Siswa pada Materi Sistem Pencernaan. Lampung: Universitas Lampung .

Kamila, H. R., \& Ducha, N. (2018). Validitas Multimedia Interaktif Model Tutorial Sistem Peredaran Darah Manusia. Pensa: Jurnal Pendidikan Sains, 6(02).

Karim, W. C. (2014). Pengaruh Penggunaan Media Pembelajaran Terhadap Motivasi Belajar Siswa. Jurnal Pendidikan Kewarganegaraan, UNG.

Kemendikbud. (2017). Materi Pendukung Literasi Sains. Jakarta: Kementerian Pendidikan dan Kebudayaan.

Latip, A., \& Permanasari, A. (2015). Pengembangan Multimedia Pembelajaran Berbasis Literasi Sains Untuk Siswa SMP Pada Tema Teknologi. Edusains, 7(2), 160-171.

OECD. (2019). PISA 2018 Assessment and Analytical Framework. OECD publishing.

PISA. (2015). Assessment and Analytical Framework: Science. Reading, Mathematic and Financial Literacy, (Interscience: Paris, 2016), 24-25.

Pratiwi, S. N., Cari, C., \& Aminah, N. S. (2019). Pembelajaran IPA Abad 21 dengan Literasi Sains Siswa. Jurnal Materi dan Pembelajaran Fisika, 9(1), 34-42.

Sanjaya, W. (2013). Penelitian Pendidikan (Jenis, Metode Dan Prosedur). Jakarta: Kencana Prenada Media Group.
Surjono, H. D. (2017). Multimedia interaktif (Konsep dan Pengembangan). Yogyakarta: UNY Press.

Yulianci, S., Gunawan, G., \& Doyan, A. (2017). Model Inkuiri Terbimbing Berbantuan Multimedia Interaktif Untuk Meningkatkan Penguasaan Konsep Fisika Peserta Didik. Jurnal Pendidikan Fisika dan Teknologi, 3(2), 146-154.

Yulianingsih, E., Habsya, C., \& Siswanto, B. (2017). Perancangan Multimedia Interaktif Sebagai Suplemen Bahan Ajar Mata Pelajaran Gambar Interior Bangunan Gedung. Indonesian Journal of Civil Engineering Education, 3(2).

Yuliyanti, T. E., \& Rusilowati, A. (2014). Analisis buku ajar Fisika SMA kelas XI berdasarkan muatan literasi sains di Kabupaten Tegal. UPEJ Unnes Physics Education Journal, 3(2).

Yulianti, Y. (2017). Literasi Sains dalam Pembelajaran IPA. Jurnal Cakrawala Pendas Vol. 3 No.2. 